\title{
ВІЗАНТІЙСЬКИЙ ЧИННИК У КОНТЕКСТІ ЄВРОПЕЙСЬКОЇ ПОЛІТИКИ ГАЛИЦЬКО-ВОЛИНСЬКОГО КНЯЗЯ РОМАНА МСТИСЛАВОВИЧА
}

\author{
T. О. Чугуй
}

Чугуй T. О. Візантійський чинник у контексті європейської політики галицько-волинського князя Романа Мстиславовича. Стаття аналізує дослідження в історіографії питання взаємин галицько-волинського князя Романа з Візантійською імперією, на основі джерельної бази розкриває особливості міждержавних відносин Русі, Візантії та європейських країн наприкінці XII - на початку XIII ст. Розглядаються питання з'ясування обставин укладення другого шлюбу Романа Мстиславовича, різні гіпотези щодо походження великої княгині Романової, зв'язок нового галицько-візантійського політичного союзу з військовими походами князя Романа на половців. Простежуються недостатньо відомі аспекти зовнішньої політики галицько-волинського правителя. Зроблено висновки про роль Романа Мстиславовича у тогочасній політичній системі. Усе це $є$ важливим для правильного розуміння історичного розвитку русько-візантійських відносин.

Ключові слова: Роман Мстиславович; Русь; Візантія; міждержавні відносини; галицько-візантійський політичний союз; військові походи.

Чугуй T. O. Византийският фактор в контекста на европейската политика на галицковолинския княз Роман Мстиславович. Статията анализира изследванията в историографията по въпроса на отношенията на галицко-волинския княз Роман с Византийската империя, на основата на изворната база разкрива особеностите на междудържавните отношения на Рус, Византия и европейските страни в края на XII - началото на XIII в. Разглеждат се выпросите за изясняване на обстоятелствата около сключването на втория брак на Роман Мстиславович, различни хипотези относно произхода на великата княгиня Романова, връзката на новия галицко-византийски политически съюз с военните походи на княз Роман срещу куманите. Проследяват се недостатъчно известни аспекти на външната политика на галицко-волинския владетел. Направени са изводи за ролята на Роман Мстиславович в тогавашната политическа система. Всичко това е важно за правилното разбиране на историческото развитие на руско-византийските отношения.

Ключови думи: Роман Мстиславович; Рус; Византия; междудържавни отношения; галицко-византийски политически съюз; военни походи.

Chuguy T. O. Byzantine Factor in the Context of the European Politics of Galich-Volyn prince Roman Mstislavovich. The paper analyses the investigations of problem of relations of Galich-Volyn prince Roman with Byzantine Empire in historiography, reveals peculiarities of interstate relations of Rus', Byzantium and European countries at the end of the 12th and the beginning of the 13th centuries on the basis of source ground. The problems of clarifying the circumstances of the second marriage of Roman Mstislavovich, different hypotheses of the origin of Great princess Romanova, the connection of the new Galich-Byzantine political union with military campaigns of prince Roman against polovtzys are considered. Little known aspects of the foreign policy of Galich-Volyn leader are traced. The conclusions about the role of Roman Mstislavovich in the political system of that time have been drawn. All this is important for proper understanding of the historical development of the Rus'-Byzantine relations.

Keywords: Roman Mstislavovich; Rus'; Byzantium; interstate relations; Galich-Byzantine political union; military campaigns.

Актуальність обраної нами теми пов'язана з недостатньо повним дослідженням в історіографії питання ролі візантійського чинника у житті князя Романа. Діяльності Романа Мстиславовича приділило увагу чимало істориків, однак питання його ролі в русько-візантійських відносинах детальніше розглянули лише В. Пашуто, Н. Полонська-Василенко, М. Левченко, М. Котляр, Д. Оболенський, С. Граля, О. Каждан ${ }^{1}$. 3-поміж новіших наукових розробок необхідно відзначити праці О. Головка, Л. Войтовича, В. Грабовецького, О. Майорова, О. Толочка, Д. Домбровського і В. Нагірного².

Особливого виділення заслуговують книги: «Роман Мстиславович, князь Волинський і Галицький» П. Кралюка ${ }^{3}$ «Князь Роман Мстиславич та його доба: нариси з історії полі- 
тичного життя Південної Русі XII - початку XIII століття» О. Головка 4 , «Галицько-волинський князь Роман Мстиславич. Володар, воїн, дипломат» О. Майорова ${ }^{5}$ i «Меч Романа Галицкого. Князь Роман Мстиславич в истории, эпосе и легендах» А. Горковенка ${ }^{6}$. Вони стали результатом аналітичного осмислення життєвого шляху князя Романа.

Незважаючи на значний комплекс робіт, здійснений переважно українськими науковцями, остаточно дослідженою тему життєдіяльності Романа Мстиславовича вважати не можна. Метою автора статті є прагнення на основі вивчення джерельної бази і наукової літератури об'єктивно прослідкувати візантійський чинник у діяльності князя Романа. 3'ясувати це питання можна на підставі таких письмових джерел, як «Галицько-Волинський» ${ }^{7}$, «Суздальський» ${ }^{8}$ i «Густинський» ${ }^{9}$ літописи, «Історія» М. Хоніята ${ }^{10}$.

Надзвичайно важливою і знаковою подією в історії України є друге й остаточне запанування Романа Мстиславовича в Галичі $1199 \mathrm{p} .{ }^{11}$ Відбулося це після смерті останнього князя $з$ династії галицьких Ростиславовичів - Володимира Ярославовича, який не залишив по собі законних спадкоємців. Посівши в Галичі, князь Роман об'єднав під своєю зверхністю два князівства - Галицьке і Волинське, утворивши Галицько-Волинське князівство, що значно значно підняло його авторитет на Русі. Саме в об'єднанні князь бачив силу, а не в роздробленості, яка на той час була притаманна багатьом європейським країнам. Будучи ще волинським правителем, Роман повів нову політику. Щоб зміцнити свою владу, він вирішив спиратися не лише на боярство, а й на міщанство.

Важливо звернути увагу на оповідання, уміщене в «Суздальському літописі» під 1202 р. У ньому подано повідомлення про порозуміння великого князя київського Рюрика Ростиславовича з чернігівськими Ольговичами. Разом вони вирішили йти військовим походом проти князя Романа, щоб відібрати в нього Галичину і настановити там князя з родини Ольговичів. Довідавшись про це, Роман Мстиславович зібрав галицькі та волинські війська і вирушив походом на Київ. «Тоді Володимировичі покинули Рюрика й поїхали до Романа, а й чорні клобуки зібралися всі й поїхали до Романа» ${ }^{12}$. Коли Роман Мстиславович підійшов до Києва, народне віче проголосило Романа своїм князем, далі мешканці міста самі відкрили йому Подільську браму на Копиревому кінці.

Внаслідок переговорів із Рюриком Ростиславовичем і Ольговичами була укладена угода: Ольговичі мали повернутися на Чернігівщину; Рюрик зрікався Києва та їхав до Вручия (Овруча), отримавши свою стару волость у Руській землі. Князь Роман вирішив не залишатися у Києві, а повернувся до Галича. «Суздальський літопис» повідомляє, що Всеволод Велике Гніздо і Роман Мстиславович посадили князем у Києві двоюрідного брата Романа - луцького князя Інгваря Ярославовича ${ }^{13}$. Показово, що «Густинський літопис» називає його намісником Романа ${ }^{14}$.

Необхідно зазначити, що в науковій літературі немає однозначного погляду на датування описаного вище походу галицько-волинського князя на Київ. Так, М. Бережков ува-

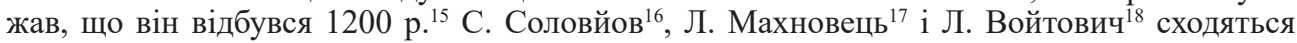
на думці, що похід був 1201 р., В. Пашуто ${ }^{19}$, Б. Рибаков ${ }^{20}$, I. Крип'якевиччㄴ, М. Котляр ${ }^{22}$ - 1202 р. М. Грушевський уважав, що ці події відносяться до 1200-1201 pp. ${ }^{23}$ О. Головко відмічає, що похід відбувся в кінці 1200 - на початку 1201 pp. ${ }^{24}$, що є найвірогіднішим.

Підтвердженням залежності Києва від Романа Мстиславовича $є$ військові походи галицько-волинського князя на половців із метою відведення загрози їхніх нападів на Руську землю. Науковці по-різному вираховували час першого переможного походу. Так, М. Котляр, аналізуючи текст «Історії» візантійського автора М. Хоніята, ще 1965 р. висловив думку про те, що перший похід відбувся в 1197-1198 pp..$^{25}$ Цю тезу згодом підтримали I. Князький ${ }^{26}$, О. Головко ${ }^{27}$, Л. Войтович ${ }^{28}$. М. Котляр уважає, що князь Роман загалом здійснив три переможні походи на половців. Час другого походу він датує зимою 1202 p. ${ }^{29}$ Натомість М. Грушевський пише, що перший похід було здійснено у кінці 1200 - або на початку 1201 pp. $^{30}$, М. Бережков - узимку 1200-1201 pp. ${ }^{31}$, Л. Войтович - влітку 1201 p. $^{32}$, Л. Махновець - узимку 1201-1202 pp..$^{33}$, М. Левченко ${ }^{34}$, О. Майоров - осінь/зима 12001201 pp. або рання весна 1201 p. ${ }^{35}$, В. Пашуто ${ }^{36}$, Б. Рибаков ${ }^{37}-1202$ р., I. Крип'якевич узимку $1202 \mathrm{p.}^{38}$ Із часом, О. Головко у справі датування походу також зупинився на зимі 1201-1202 pp. ${ }^{39}$

На наш погляд, військовий похід князя Романа відбувся взимку 1200-1201 рр., оскільки М. Хоніят у своєму тексті чітко називає Романа Мстиславовича князем галицьким, а 
його військо - численним ${ }^{40}$. Навряд чи міг Роман ще до створення об'єднаного ГалицькоВолинського князівства мати достатньо можливостей, щоб надати серйозну військову допомогу Візантійській імперії в боротьбі з половцями. Крім того, вже у кінці 1201 - на початку 1202 рр. було укладено мирний договір між Візантією і Болгарією. Половці відтоді мали захищати свої землі й не могли допомагати болгарам у нападах на Візантію. Імперія визнала незалежність Болгарії, при цьому повернула собі території Фракії.

Таким чином, узимку 1200-1201 pр. половці вдерлися на Переяславщину і Київщину. Князь Роман наздогнав нападників уже тоді, коли вони поверталися назад, за р. Рось: «... узяв (Роман) половецькі вежі й привів багато полонених. Він відібрав також від них (половців) дуже багато християн (невільників)» ${ }^{41}$. Зауважимо, що похід Романа Мстиславовича відбувся без підтримки інших впливових князів Південно-Західної Русі.

Похід на половців був викликаний тим, що князь Роман мав дружні відносини з Візантією. Відомо, що у травні 1200 р. у Константинополі перебувало посольство від галицьковолинського князя, яке очолював боярин Твердята Остромирич ${ }^{42}$. Наявність цього посольства $є$ доказом добросусідських відносин. На думку О. Майорова, Роман Мстиславович у цей час удруге одружився. Його обраницею стала родичка візантійського імператора Алексія III Ангела - Сфросинія. Шлюб «мав укріпити новий воєнно-політичний союз» ${ }^{43}$. Л. Махновець датує укладення другого шлюбу князя Романа $1200 \mathrm{p}^{44}$ Л. Войтович пише, що союз із Візантією «не тільки підняв престиж Романа, але й сприяв його закріпленню на галицькому престолі» ${ }^{45}$.

Дискусія щодо питання походження другої дружини Романа Мстиславовича триває вже багато часу. Існує декілька версій походження великої княгині Романової. За однією 3 них, княгиня походила 3 волинських бояр. Про це писали В. Пашуто ${ }^{46}$, Н. ПолонськаВасиленко ${ }^{47}$, М. Котляр ${ }^{48}$, О. Головко ${ }^{49}$. Згодом О. Головко почав схилятися до версії про візантійське походження княгині ${ }^{50}$. Заперечили версію про боярське походження княгині дослідники Я. Беняк $\kappa^{51}$ і П. Грицак ${ }^{52}$. Останній зауважив, що вона була споріднена 3 угорською, польською і візантійською династіями.

Згідно $з$ версією Л. Дроби ${ }^{53}$, В. Абрагама ${ }^{54}$, Б. Влодарського ${ }^{55}$, В. Луціва ${ }^{56}$, Ю. Форсманна $^{57}$, княгиня була католичкою. Існують навіть такі версії, як здогад М. Чубатого про те, що княгиня була донькою Святослава Мстиславовича або Інгваря Ярославовича ${ }^{58}$. Проте, такий шлюб був би порушенням церковних канонів. О. Толочко пішов іще далі, припустивши, що друга дружина князя Романа походила 3 простолюдинів, а їхній шлюб був незаконним ${ }^{59}$. Проте, навряд чи угорський король і малопольський князь підтримували б велику княгиню Романову після загибелі ії̈ чоловіка 1205 р., коли вона б не мала знатного походження.

М. Грушевський називав другу дружину галицько-волинського князя «католицькою принцесою» ${ }^{60}$. С. Томашівський ${ }^{61}$, І. Крип'якевич ${ }^{62}$, не заглиблюючись у питання походження великої княгині Романової, відмітили, що вона була ятрівкою, тобто жінкою брата угорського короля Андрія II. Варто зауважити, що Роман і Андрій II - троюрідні брати, а великий князь київський Мстислав Володимирович був прадідом Романа Мстиславовича, Андрія II і Лешка Бялого.

Незважаючи на те, що російський візантиніст О. Каждан висловив сумнів щодо візантійського походження другої дружини князя Романа та іiї спорідненості з династією Ангелів, назвавши версію М. Баумгартена - гіпотезою ${ }^{63}$, їі дотримується ціла низка дослідників, зокрема Й. Майлат ${ }^{64}$, М. Баумгартен (найвірогідніше донька Iсаака II від першого шлюбу ${ }^{65}$, Є. Граля ${ }^{66}$, Д. Домбровський ${ }^{67}$, Л. Войтович ${ }^{68}$, О. Майоров ${ }^{69}$, В. Нагірний ${ }^{70}$. Цікаво, що версія про візантійське походження другої дружини Романа Мстиславовича має декілька підверсій. Так, на думку Є. Гралі - Марія (чернече ім'я - Анна) походила зі знатного візантійського роду Каматеросів і була родичкою імператриці Сфросинії, дружини Алексія III Ангела. Шлюб Романа з Марією дослідник датує 1199 р.71 Цікаво, що в 1198-1206 рр. Константинопольським патріархом був Іоанн Х Каматерос, який міг вплинути на митрополита Київського, щоб він дозволив князеві Роману вдруге одружитися.

На думку Л. Махновця ${ }^{72}$, яку згодом підтримав Д. Домбровський ${ }^{73}$, друга дружина князя Романа могла бути донькою імператора Ісаака II Ангела і його другої дружини Маргарити-Марії. Однак О. Майоров заперечує це через надто юний вік Маргарити-Марії 
Угорської і пізніші плани іï брата - короля Андрія II видати свою доньку Марію заміж за Данила Романовича ${ }^{74}$. О. Майоров уважає, що великою княгинею Романовою могла були старша донька імператора Iсаака II Ангела, яка тривалий час була черницею ${ }^{75}$. Її світське ім'я було Єфросинія, а чернече - Марія або Анна ${ }^{76}$. Після двірцевого перевороту 1195 р. візантійським імператором став ії дядько - Алексій III Ангел, який згодом повернув племінницю з чернецтва, що було можливим у Візантії, і видав заміж за князя Романа близько 1200 p. $^{77} 3$ часом, Л. Войтович також дійшов висновку про те, що версія Л. Махновця не відповідає хронології ${ }^{7}$.

Важливим дискусійним питанням є час другого одруження Романа Мстиславовича. Так, якщо Є. Граля ${ }^{79}$, Д. Домбровський ${ }^{80}$ і В. Нагірний ${ }^{81}$ уважають, що ця подія відбулася 1199 р., то Л. Войтович ${ }^{82}$ і О. Майоров ${ }^{83}-1200$ р., а О. Толочко ${ }^{84}$ - кінець 1202 - початок 1203 pp. На нашу думку, князь Роман міг удруге одружитися не раніше 1200 p.

Отже, галицько-волинський князь Роман уклав із Візантією союзну угоду про спільні дії проти половців. Невипадково візантійський історик М. Хоніят повідомляє, що похід князя Романа на половців був викликаний жалем до людей Візантії, над якою нависла половецька загроза (особливо після болгарсько-половецької угоди 1186 р.). За словами М. Хоніята, князь галицький Роман, швидко приготувавшись, зібрав хоробру і численну дружину, напав на куманів (половців), розграбував і спустошив їхню землю. Повторив це декілька разів, зупинивши набіги куманів, надавши єдиновірному народу несподівану допомогу ${ }^{85}$. Історик також зазначає те, що Роман Мстиславович розпочав боротьбу 3 половцями на прохання імперії, поступаючись благанням свого архіпастиря.

Візантійський історик Ф. Скутаріот у «Хроніці Аноніма Сафи» пише, що наступного року після куманів (половців), влахи, вирушивши в похід, без втрат повернулися додому. Вони не переставали б нападати на Візантію, якби не найхристиянніший народ роси не виступив мужньо проти них на прохання імператора. Правитель Галичини Роман зібрав численне й достославне військо, раптово напав на землю куманів, зруйнував і знищив іiі, зробивши це багато разів на славу християнській вірі. Так він зупинив набіги куманів ${ }^{86}$.

Не можна забувати і ще про один важливий чинник. Зайнявши пониззя Дністра і Дунаю, половці перекрили торговельний «Бурштиновий шлях» від Балтійського моря через Галич по Дністру до Понту (Чорного моря). Це могла бути ще одна причина військового походу Романа Мстиславовича на половців, адже від виходу до моря залежала торгівля в південно-східному напрямі.

Незалежно від причин, що зумовили військовий похід, він виявився вдалим. Унаслідок цього до Галицько-Волинського князівства знову були приєднані території пониззя Дністра і Дунаю, удалося відвернути половецьку загрозу від Візантії. Авторитет князя Романа значно зріс не тільки на Русі, а й за їі межами.

Встановлення влади галицько-волинського князя Романа Мстиславовича над Києвом викликало обурення в Рюрика Ростиславовича. Він на початку січня 1203 р. разом із чернігівськими Ольговичами і половцями зайняли, пограбували і попалили Київ. Літописець так охарактеризував те, що сталося: «... такого лиха не було над Києвом від хрещення» ${ }^{87}$ Усе це зробив Рюрик, який донедавна завзято обороняв Київ від половців, щоб відомстити киянам за їхній перехід на бік Романа. Після такого страшного погрому міста, князь Рюрик не зостався у Києві, а відправився у Вручий, залишивши в столиці свою військову залогу. На думку М. Грушевського, справжнім автором другого погрому Києва був володимиросуздальський князь Всеволод Велике Гніздо, оскільки він, згідно з даними «Суздальського літопису», дуже легко пробачив руйнування Руської землі, будучи «боголюбивим» $\mathrm{i}$ «милосердним» ${ }^{88}$.

Дізнавшися про трагічні події, Роман Мстиславович вирушив до Вручия. 16 лютого 1203 р. було укладено угоду, згідно з якою Рюрик Ростиславович став правителем Києва, відмовившись при цьому від союзу з Ольговичами і половцями. Підтвердженням вищого статусу Романа, ніж Рюрика $є$ те, що у Візантії визнавали Романа Мстиславовича великим князем (igemon), а Рюрика - лише правителем (diepon) Києва ${ }^{89}$. У Новгороді також називали Романа великим князем ${ }^{90}$.

Цілком можливо, що київські справи не пройшли без втручання Всеволода Велике Гніздо. Проте, на наш погляд, $є$ помилковою думка Дж. Феннела про те, що реальна влада на Русі продовжувала зосереджуватися в руках суздальського князя ${ }^{11}$. Натомість слушною 
є теза О. Головка ${ }^{92}$, котру згодом підтримав М. Кучинко, згідно з якою князь Роман створив систему «колективного патронату» над столицею двох наймогутніших володарів на Русі ${ }^{93}$. О. Майоров називає цю систему «колективним сюзеренітетом» ${ }^{94}$.

Саме тут яскраво проявилася мудрість, витривалість і гнучкість галицько-волинського князя Романа, його прагнення встановити мир у Руській землі. Як наслідок - союз Рюрика Ростиславовича з Ольговичами і половцями було зруйновано, а вже в першій половині 1203 р. відбувся спільний військовий похід князів Романа Мстиславовича, Рюрика Ростиславовича 3 племінниками Мстиславовичами і сина Всеволода Велике Гніздо - Ярослава переяславського на половців. На думку О. Головка, цим походом Роман здійснив свій намір - розколоти, посварити й ослабити своїх суперників ${ }^{95}$. Варто зауважити, що військовий похід був спрямований також для захисту інтересів Візантії.

Історики по-різному вираховують датування другого військового походу князя Романа на половців. Так, І. Крип'якевич ${ }^{96}$ і М. Котляр ${ }^{97}$ пишуть, що він відбувся взимку 1204 р. М. Грушевський називав часом походу зиму $1203-1204$ pp. $^{98}$, Б. Рибаков ${ }^{99}$ і Л. Войтович ${ }^{100}$ уважають, що це було 1203 р., Л. Махновець ${ }^{101}$, Дж. Феннел ${ }^{102}$ і О. Головко ${ }^{103}-$ пізньою зимою 1203 або ранньою весною 1204 pp., М. Волощук - 1204 p. ${ }^{104}$ О. Толочко - 1205 p. ${ }^{105}$ О. Майоров пише, що похід мав статися у березні 1203 р., ще до першої облоги Константинополя в липні 1203 p. ${ }^{106}$ Такий висновок $є$ найвірогіднішим.

Головним $\epsilon$ те, що похід виявився дуже вдалим. Закінчився він повною перемогою $\mathrm{i}$ взяттям у полон великої кількості половців і визволенням невільників. Із приводу походів Романа Мстиславовича на половців у «Галицько-Волинському літописі» пишеться: «Він бо кинувся був на поганих, як той лев, сердитий же був, як та рись, і губив [ïx], як той крокодил, і переходив землю їх, як той орел, а хоробрий був, як той тур, бо він ревно наслідував предка свого Мономаха ...» ${ }^{107}$.

Виникає закономірне питання, у чому криється секрет успіху військових походів князя Романа на половців? Відповідь - галицько-волинський князь перед цим реформував своє військо. Головними змінами стали: заміна кольчуги на вдосконалений панцир, перетворення руської кінноти на важкоозброєну лицарську кінноту. На думку дослідника військової справи В. Кійка, Роман Мстиславович створив одну з кращих кінних дружин у Східній Європі, запровадивши залізні нагрудники і шоломи «латинські» ${ }^{108}$.

У середовищі руських князів, які поверталися з походу на половців, на раді у Треполі виникла суперечка щодо розподілу волостей у Руській землі відповідно до особистого внеску в її захист. Розгніваний Роман Мстиславович «піймав Рюрика, післав (його) до Києва й постриг у черці, так само його жінку й дочку ...» ${ }^{109}$. Згідно 3 даними «Новгородського літопису», волинського боярина-воєводу В'ячеслава князь Роман того ж літа скерував до Києва, щоб там постригти Рюрика у ченці ${ }^{110}$. Крім того, Роман Мстиславович забрав у Рюрика всі його волості у Руській землі. М. Хоніят із цього приводу написав, що Роман, як міцніший силою і славніший мистецтвом, здобув перемогу, при цьому також знищив багато куманів, які допомагали в боротьбі Рюрику, складаючи сильнішу і могутнішу частину його війська ${ }^{111}$.

Підпорядкувавши собі Київ, Роман Мстиславович пробув у ньому два тижні й відправився до Галича, залишивши правителем у Києві Інгваря Ярославовича. Згодом, на прохання Всеволода Велике Гніздо, князь Роман настановив правителем у Києві зятя володимиро-суздальського князя - Ростислава Рюриковича ${ }^{112}$, який став васалом галицьковолинського володаря. Чернігівські ж Ольговичі визнали такий стан справ на Русі.

Отже, Роман Мстиславович фактично став господарем у Руській землі, піднісши свою владу над Києвом. На наш погляд, це стало можливим завдяки успішним походам на половців, оскільки військові перемоги різко піднесли авторитет галицько-волинського князя. М. Грушевський слушно зауважив, що ці чинники зробили Романа «зверхником українських земель» ${ }^{113}$. Дійсно, у землях Південно-Західної Русі в ті часи не було жодного настільки могутнього князя. Не випадково «Галицько-Волинський літопис» називає Романа Мстиславовича «великим князем», «вікопомним самодержцем усієї Русі»» ${ }^{114}$. Цікаво, що це $\epsilon$ перше вживання терміну самодержець щодо руського князя у літописі.

П. Толочко й О. Толочко вірно зауважили, що відновлення політичної єдності Південної Русі від Карпат і Дунаю до Дніпра «було видатною подією в її державному житті, хоча й не здавалося Романові кінцевою метою його державницьких амбіцій» ${ }^{115}$. Про те, 
що князь Роман не просто прагнув мати велику владу, а й хотів максимально використати iї для розв'язання нагальних проблем Русі, переконливо свідчить проект «доброго порядку». Зміст цього проекту під 1203 р. першим переказав російський історик В. Татищев ${ }^{116}$.

Головна мета проекту «доброго порядку» - запровадження у шести основних руських князівствах майорату для забезпечення цілісності Русі, на чолі якої мав стояти могутній великий князь київський. Останнього мали спільно обирати шість найсильніших («старших») князів (володимирський (суздальський), чернігівський, галицький, смоленський, полоцький і рязанський). Інші, незначні за впливом князі («молодші»), повинні були прийняти рішення «старших», виконувати їхні ухвали та доручення. У випадку виникнення князівських міжусобиць, великий князь київський мав право засудити нападника й помирити ворогів, а у разі потреби - застосувати військову силу разом із місцевими князями для відновлення порядку. У ситуації, коли одному з князів загрожували б іноземні вороги і він сам не взмозі дати збройну відсіч, великий князь київський, узгодивши $з$ іншими «старшими» князями, направляє допомогу від усієї Русі. Задум Романа Мстиславовича це ідея, котра могла сконсолідувати князів, об'єднати руські землі, припинити міжусобиці. Як вірно зауважив М. Котляр, проект «доброго порядку» свідчить про те, що князь Роман «був людиною, яка стояла на голову вище від багатьох інших князів і феодалів, відзначалася неабиякою державною мудрістю» ${ }^{117}$.

Маємо зауважити: проект «доброго порядку» з'явився внаслідкок активного розвитку русько-візантійсько-німецьких відносин. Так, на думку О. Майорова, князь Роман 1203 р. міг відвідати Ерфурт, де зустрівся з Філіппом Швабським, який був одружений з рідною сестрою (Іриною) другої дружини галицько-волинського правителя (Єфросинії) $)^{118}$. Дослідник уважає, що проект «доброго порядку» виник під впливом відвідин Романом Мстиславовичем Німеччини влітку 1203 р., ймовірно восени того ж року [Там само]. Л. Войтович також зазначає, що князь Роман при створенні проекту «доброго порядку» запозичив ідеї німецького проекту Вельфів ${ }^{119}$, який регламентував вибори імператора Священної Римської імперії. Таким чином, налагодження русько-німецьких відносин відбулося завдяки візантійським родинним зв'язкам.

Однак проектові «доброго порядку» не судилося здійснитися. На пропозицію князя Романа зустрітися на з'їзді у Києві й обговорити це питання з метою створення чіткого статуту, князі не погодилися. Це переконливо свідчить про те, що вони остерігалися прагнень галицько-волинського правителя зменшити їхній суверенітет. Незважаючи на ці обставини, Роман Мстиславович залишався повноправним господарем усієї Правобережної України-Русі.

Великий авторитет галицько-волинського князя підтверджується характером його відносин із правителями інших держав. Добрими вони були з Андрієм II (Ендре), якого Роман Мстиславович підтримував у боротьбі за угорський престол проти його брата Емеріка (Імре), союзника німецького імператора Оттона IV Вельфа. У першій половині 1205 р. Андрій II став угорським королем. Відомо також, що між Романом, Андрієм II і польським князем Лешком Бялим існувала угода, згідно з якою у разі загибелі одного 3 правителів, інші мали опікуватися його дітьми, взявши їх під свій захист ${ }^{120}$.

Були широковідомі на Русі та за її межами зв'язки князя Романа з візантійським імператорським двором. Саме цим пояснюється поява напівлегенди, пов'язаної з іменем галицько-волинського князя - оповідання про втечу візантійського імператора Алексія III Ангела до Галичини після взяття хрестоносцями в облогу Константинополя під час IV Хрестового походу в 1203 р. Алексій III був милостиво і прихильно прийнятий князем Русі Романом і деякий час перебував у нього ${ }^{121}$.

Оповідання визнали таким, що відображає справжні події, Д. Зубрицький, М. Дашкевич, О. Андріяшев, В. Мавродін, Д. Лихачов, Т. Коструба, Ю. Форсманн, Г. Прінцінг, Б. Рибаков, Д. Александров, В. Борисенко, Н. Яковенко, В. Грабовецький, Я. Ісаєвич, Л. Войтович, В. Ідзьо ${ }^{122}$. М. Грушевський, В. Нагірний висловили сумніви щодо його реальності ${ }^{123}$. М. Котляр узагалі заперечив можливість перебування Алексія III в Галичині ${ }^{124}$. Є. Граля вважає, що Длугошовий Аскарій - це не Алексій III, а нікейський імператор Феодор I Ласкаріс, який свого часу втік із Константинополя до Херсонесу Фракійського і Галатії в Малій Азії ${ }^{125}$. Проте це твердження спростував О. Майоров ${ }^{126}$. 
Для того, щоби розібратися у цьому складному питанні, необхідно провести реконструкцію історичних подій. Варто відзначити: візантійський імператор Алексій ІІІ уперше рятувався втечею з Константинополя ще 1202 р. Він попрямував до Німеччини, до короля Філіппа Швабського, якого просив повернути йому трон ${ }^{127}$. Король Філіпп дійсно втрутився і посприяв вирішенню цього питання.

Друга втеча Алексія III відбулася в ніч на 18 липня 1203 р. під час першого штурму Константинополя хрестоносцями. Зі столиці Візантійської імперії Алексій III швидко попрямував у Девельт (Бургас), після чого далі, у Адріанополь ${ }^{128}$. Туди ж навздогін вирушив і новий імператор, племінник Алексія III - Алексій IV. Шукаючи свого попередника, він обійшов міста Фракії.

У хроніці «Балдуїн Константинопольський» і «Генуезьких анналах» указується, що 3 Константинополя Алексій III утік до «короля валахів» ${ }^{129}$, тобто болгарського царя Івана Калояна, коронованого у листопаді 1204 р. папським легатом королівською короною. У «Новій церковній історії» 1294-1313 рр. Бартоломео дель Фіядоні (Птолемей із Лукки) писав, що візантійський імператор Аскарій з Константинополя попрямував до Херсонесу, звідти до Галатії, яка нині $є$ частиною Русі ${ }^{130}$. Цікаво, що в іноземних джерелах, особливо арабських, візантійські імператори іменуються «Ласкарісами» незалежно від їхніх справжніх імен ${ }^{131}$. Тому О. Майоров справедливо вважає, що це міг бути тільки Алексій III $^{132}$. На цьому тлі логічним $є$ висновок Л. Войтовича про те, що союз Візантії з Галицько-Волинською державою «був, безперечно, чи не найбільшим зовнішньополітичним успіхом династії Ангелів» ${ }^{133}$, оскільки галицько-волинський князь Роман виявився надійним політичним союзником.

Далі доля Алексія III склалася наступним чином. У квітні 1204 р. він з’явився в Мосінополі. На зустріч до Алексія III прибув його зять, новий візантійський імператор Алексій V Мурчуфл, який перед цим убив Алексія IV. Проте й він утік з Константинополя в ніч на 13 квітня 1204 р. Того ж дня імператором було проголошено Константина Ласкаріса, який через декілька годин також утік з Константинополя, після чого хрестоносці взяли столицю штурмом.

За наказом Алексія III, його зятя - Алексія V осліпили. В середині червня 1204 p. імператор нової Латинської імперії Балдуїн (Бодуен) I змусив Алексія III тікати до Фессалоніки, яка в серпні 1204 р. перейшла під владу Балдуїна І. При спробі втечі з обложеного Корінфа весною 1205 р. Алексій III потрапив у полон до маркіза Боніфація Монферратського (головнокомандувача хрестоносців, родича і сподвижника Філіппа Швабського). Боніфацій відправив Алексія III до своїх володінь в Італії. У 1208-1209 рр. полоненого викупив його двоюрідний брат - правитель Епіру Михаїл I Ангел. Після цього Алексій III разом із іконійським султаном Гійасом ад-діном Кай-Хосровом I розпочав боротьбу за владу з Феодором I Ласкарісом - імператором Нікейської імперії, що постала на уламках Візантії. У битві біля Антіохії 17 червня 1211 р. Алексій III потрапив у полон і був осліплений, після чого ув'язнений в одному з монастирів Нікеї, де згодом і помер.

На думку О. Майорова, зміни у ставленні Романа Мстиславовича до католицької церкви відбулися в останні роки його життя і були пов'язані саме 3 подіями IV Хрестового походу, захопленням і пограбуванням Константинополя ${ }^{134}$. Тому не дивно, що коли папа Римський Інокентій III, дізнавшися про славні перемоги князя Романа, 1204 р. скерував до нього послів із пропозицією перейти до католицької віри (за це він обіцяв Романові королівську корону і допомогу меча Св. Петра для подальших завоювань) ${ }^{135}$. Проте князь Роман рішуче відмовився від пропозиції понтифіка, виразивши таким чином своє ставлення до католицтва. Л. Войтович допускає, що відмова Романа Мстиславовича від королівської корони відбулася внаслідок переговорів із Алексієм III ${ }^{136}$.

На характері відносин князя Романа з Інокентієм III також відбивалися його стосунки 3 німецькими правителями. Галицько-волинський володар підтримував родину Гогенштауфенів у її боротьбі за імператорський престол Священної Римської імперії. Відповідно він виступав проти родини Вельфів, яких у ті часи підтримував папа Римський.

Відносини князя Романа з польськими правителями були непростими. Після смерті Мешка III Старого 13 лютого 1203 р. малопольський князь Лешко Бялий фактично став сюзереном польських земель. Знаючи це, Роман Мстиславович захотів отримати винагороду від Лешка Бялого за свою попередню допомогу. Однак той не погодився на це. Тоді 
навесні 1204 р. галицько-волинський князь здійснив військовий похід на Малу Польщу до Сандомира, «... два города взя и много попустоши ... воспятися не взяв мира» ${ }^{137}$.

Наступний похід Романа Мстиславовича до Сандомира був зумовлений тим, що на запрошення краківської громади, після короткого князювання великопольського князя Владислава Тонконогого, Лешко Бялий відмовився повернутися до Кракова, викликавши гнів у князя Романа. Галицько-волинський князь вирушив до Сандомира, «... нача более разоряти и села жечи» [Там само]. Ще одна мета походу - помста Лешкові Бялому через невиплату грошей за колишню допомогу. В тій ситуації малопольському князю необхідний був мир, тому він направив послів до Романа Мстиславовича, який відповів, що не хоче більше плюндрувати польські землі, а вимагає заплатити сріблом або віддати Люблінщину ${ }^{138}$.

Князь Роман 1205 р. здійснив ще один військовий похід на захід, про що тогочасні джереда подають мало інформації. Мета походу в руських літописах також не називається. Лише французький хроніст середини XIII ст. Альбрік з монастиря Труа Фонтен (Трьох Джерел) озвучує їі. Він писав, що король Русі Роман вирушив зі своїх володінь, маючи намір через Польщу попрямувати до Саксонії, як удаваний християнин хотів зруйнувати церкви, але два брати Лешко і Конрад над річкою Вісла з волі Божої перемогли його і вбили, а всіх тих, хто був 3 ним розігнали або знищили ${ }^{139}$. На думку I. Паславського, інформація Альбріка про церкви може бути відлунням якогось непорозуміння між галицько-волинським князем і Римською курією ${ }^{140}$. О. Майоров уважає, що це лише стилістичний зворот ${ }^{141}$.

Таким чином, участь галицько-волинського князя в німецькій політиці є цілком вірогідною. Пройшовши через Польщу в Саксонію, Роман прагнув нанести удар її володарю - імператору Оттонові IV Брауншвейгському, тим самим допомогти синові Фрідріха I Барбаросси - Філіппові Швабському - в його намаганні посісти імператорський трон. Але на території Польщі галицько-волинський князь натрапив на Лешка Бялого. На думку Г. Лябуди, у першій половині 1205 р. існував політичний союз князя Романа і великопольського князя Владислава Тонконогого ${ }^{142}$. Б. Влодарський, В. Пашуто і Н. Щавелева зазначають, що посварив Романа Мстиславовича з Лешком Бялим якраз Владислав Тонконогий 3 метою завадити галицько-волинському князеві надати допомогу Філіппові Швабському, проти якого виступив король Данії Вальдемар $\mathrm{II}^{143}$.

У «Суздальському літописі» знаходимо наступні слова: «Того ж року (1205) пішов Роман галицький на ляхів і зайняв два лядські городи. Але як дійшов до ріки Висли, від'їхав сам із малою дружиною від свого війська, а ляхи наїхали, вбили його й побили коло нього дружину» ${ }^{144}$. Так, поставивши перед собою амбіційну мету об'єднати руські землі, у розквіті сил, через прикрий випадок - польську засідку - загинув видатний державний діяч України-Русі князь Роман Мстиславович. Він був правителем, велична слава якого розійшлася далеко за межі його володінь. Однак планам галицько-волинського князя не судилося здійснитися. 3 його смертю Русь фактично втратила унікальну можливість відновити свою попередню славу. На думку Л. Войтовича, князь Роман «був політиком європейського масштабу, який реально впливав на перебіг подій у Європі» ${ }^{14}$.

Отже, створення Романом Мстиславовичем Галицько-Волинського князівства висунуло князя на одне 3 перших місць серед руських правителів, дало можливість установити свою владу в Києві, об'єднати землі України-Русі від Карпат до Дніпра. У цьому процесі важливу роль відіграло укладення галицько-візантійського політичного союзу та пов'язані 3 ним успішні військові походи на половців. На цьому фоні виглядають логічними версія про візантійське походження великої княгині Романової й оповідання про втечу візантійського імператора Алексія III Ангела до Галичини.

Заслугою князя Романа $є$ те, що він проявив себе не лише як хоробрий полководець, а й як державний діяч, ініціювавши надзвичайно необхідний проект «доброго порядку», котрий мав на меті припинити князівські міжусобиці, зміцнити владу великого князя київського, перетворити Русь на конфедерацію. Той факт, що європейські правителі, у переважній більшості, прагнули краще підтримувати добрі відносини, ніж ворогувати 3 галицько-волинським правителем, $є$ переконливим підтвердженням його авторитету і могутності. Заслуга Романа Мстиславовича полягає у тому, що він зумів піднятися над дріб'язковими інтересами удільних руських князів і стати одним із видатних державних діячів останньої третини XII - початку XIII ст. 
${ }^{1}$ Пашуто В. Т. Очерки по истории Галицко-Волынской Руси. М.: Изд-во АН СССР, 1950. 330 с.; Його ж. Внешняя политика Древней Руси. М.: Наука, 1968. 474 с.; Полонська-Василенко Н. Княгиня Романова Ганна // Визвольний шлях. 1954. Кн. 3. С. 57-64; Левченко М. В. Очерки по истории русско-византийских отношений. М.: Изд-во АН СССР, 1956. 556 с.; Котляр М. Ф. Чи міг Роман Мстиславич ходити на половців раніше 1187 р. // Український історичний журнал (далі УІЖ). 1965. № 1. С. 117-120; Його ж. До питання про втечу візантійського імператора в Галич у 1204 р. // УІЖ. 1966. № 3. С. 112-117; Його ж. До питання про візантійське походження матері Данила Галицького // Археологія. 1991. № 2. С. 48-58; Його ж. Роман Великий // Історія України в особах IX-XVIII ст. / За ред. В. Замлинського. К.: Україна, 1993. С. 107-114; Його ж. Княгиня Анна // Історія України в особах IX-XVIII ст. / За ред. В. Замлинського. К.: Україна, 1993. С. 114-119; Його ж. Галицько-Волинська Русь // Україна крізь віки: у 15 т. К.: Альтернативи, 1998. Т. 5. 336 с.; Його ж. Дипломатія галицьких і волинських князів XII-XIII ст. // Київська старовина. 2000. № 5. С. 3-10; Його ж. Данило Галицький: біографічний нарис. К.: Альтернативи, 2002. 328 с.; Його ж. Історія дипломатії Південно-Західної Русі. К.: Ін-т історії України НАН України, 2002. 247 с.; Його ж. Воєнне мистецтво Давньої Русі. К.: Наш час, 2011. 280 с.; Його ж. Галицко-Волынская Русь и Византия в XII-XIII вв. (связи реальные и вымышленные) // Южная Русь и Византия: Сб. науч. трудов (к XVIII конгрессу византинистов). К.: Наукова думка, 1991. С. 20-33; Його ж. Дипломатия Южной Руси. СПб.: Алетейя, 2003. 300 с.; Оболенский Д. Связи между Византией и Русью в XI-XV вв. // XIII Международный конгресс исторических наук (Москва, 16-23 августа 1970 г.). М.: Наука; Главная редакция восточной л-ры, 1970. С. 5-6; Grala H. Drugie małżeństwo Romana Mścisławowicza // Slavia Orientalis. Warszawa, 1982. R. 31. № 3-4. S. 115-127; Його ж. Rola Rusi w wojnach bizantyńsko-bułgarskich przełomu XII i XIII w. // Balcanica Posnaniensia. Acta et Studia. Poznań, 1985. T. 2. S. 128-131; Його ж. Tradycija dziejopisarska o pobycie władcy Bizancjum w Haliczu (Jan Długosz i kronikars Hustyński) // Kwartalnik Historyczny. 1986. R. 93. № 3. S. 639-661; Kazhdan A. Ruś - Byzantine Princely Marriages in the Eleventh and Twelfth Centuries // Harvard Ukrainian Studies. 1988-1989. T. 12-13. P. 414-429.

2 Головко О. Б. Південна Русь і половецький степ у політичній діяльності галицьковолинського князя Романа Мстиславича // Українська козацька держава: витоки та шляхи історичного розвитку: матеріали Других Всеукраїнських читань). Черкаси, 1992. С. 15-17; Його ж. Князь Роман Мстиславич та його доба: нариси з історії політичного життя Південної Русі XII - початку XIII століття. К.: Стилос, 2001. 249 с.; Його ж. Корона Данила Галицького: Волинь і Галичина в державно-політичному розвитку Центрально-Східної Європи раннього та класичного середньовіччя. К.: Стилос, 2006. 575 с.; Його ж. Візантійська імперія, Південна Русь і Половецький степ в політичній діяльності галицько-волинського князя Романа Мстиславича // Орієнтальні студії в Україні. До ювілею Л. В. Матвєєвої. К.: Ін-т сходознавства ім. А. Ю. Кримського, 2010. С. 192-208; Войтович Л. В. Князівські династії Східної Європи (кінець IX - початок XVI ст.): склад, суспільна і політична роль: історико-генеалогічне дослідження. Львів: Ін-т українознавства ім. І. Крип'якевича НАН України, 2000. 649 с.; Його ж. Княжа доба на Русі: портрети еліти. Біла Церква: Вид. О. Пшонківський, 2006. 784 с.; Його ж. Мати короля Данила (зауваження на полях монографії Д. Домбровського) // Княжа доба. Історія і культура. Вип. 1. Львів: Ін-т українознавства ім. І. Крип'якевича, 2007. С. 45-58; Його ж. Союз Візантії та Галицько-Волинської держави за династії Ангелів // Княжа доба: історія і культура. Вип. 2. Львів: Ін-т українознавства ім. І. Крип'якевича НАН України, 2008. С. 30-39; Його ж. Галицькоболгарські відносини в першій третині XIII століття // Княжа доба: історія і культура. Вип. 3. Львів: Ін-т українознавства ім. І. Крип'якевича НАН України, 2010. С. 201-212; Його ж. Галицька земля i Візантія у XI-XIV століттях // Дрогобицький краєзнавчий збірник. Вип. 14-15. Дрогобич: Коло, 2011. С. 37-60; Його ж. Галицько-Волинські етюди. Біла Церква: Вид. О. Пшонківський, 2011. 480 с.; Його ж. Галич у політичному житті Європи XI-XIVстоліть. Львів: Ін-т українознавства ім. I. Крип'якевича НАН України, 2015. 478 с.; Грабовецьький B. В. Галич - столиця Ростиславовичів i Романовичів у міжнародних взаєминах XII-XIII ст. // Галич і Галицька земля: зб. наук. праць / Відп. ред. П. П. Толочко. К.; Галич: ІА НАНУ; НЗ «Давній Галич», 1998. С. 43-83; Майоров А. В. Малоизвестные источники по истории русско-византийских отношений начала XIII века: текст, перевод, комментарий // Український історичний збірник. Вип. 12. К., 2009. С. 294-297; Його ж. Ангел в Галичі: чи міг візантійський імператор Олексій III відвідувати Романа Мстиславича // Княжа доба: історія і культура. Вип. 3. Львів: Ін-т українознавства ім. І. Крип’якевича НАН України, 2010. С. 133-164; Його ж. Галицько-волинський князь Роман Мстиславич. Володар, воїн, дипломат: у 2 т. Біла Церква: Вид. О. В. Пшонківський, 2011. Т. 1. 318 с.; Т. 2. 462 с.; Його ж. Русь, Византия и Западная Европа. Из истории внешнеполитических и культурных связей XII-XIII вв. СПб.: Изд. Д. Буланин, 2011. 800 с.; Його ж. Єфросинія Галицька. Дочка візантійського імператора в Галицько-Волинській Русі: княгиня і черниця. Біла Церква: Вид. О. В. Пшонківський, 2013. 224 с.; Толочко О. П., Толочко П. П. Київська Русь // Україна крізь віки: у 15 т. К.: Альтернативи, 1998. Т. 4. 352 с.; Толочко А. П. «История Российская» Василия Татищева: источники и известия. М.: Новое литературное обозрение; К.: Критика, 2005. 544 с.; Його ж. Як звали другу дружину 
Романа Мстиславича // Confraternitas. Ювілейний збірник на пошану Я. Ісаєвича / Відп. ред. М. Крикун // Україна: культурна спадщина, національна свідомість, державність: Зб. наук. пр. Вип. 15. Львів: Ін-т українознавства ім. І. Крип'якевича НАН України, 2006-2007. С. 98-102; Иого ж. Известен ли год рождения Даниила Романовича Галицкого? // Средневековая Русь. 2007. № 7. C. 221-236; Dabrowski D. Rodowód Romanowiczów książąt halicko-wołyńskich. Poznań; Wrocław: Wydawnictwo Historyczne, 2002. 347 s.; Його ж. Genealogia Mścisławowiczów. Pierwsze pokolenia (do początku XIV wieku). Kraków: Awalon, 2008. 780 s.; Nagirnyj W. Polityka zagraniczna księstw ziem Halickiej i Wołyńskiej w latach 1198(1199)-1264 // Prace Komisji wschodnioeuropejskiej PAU / Pod red. A. A. Zięby. Kraków: PAU, 2011. T. 12. 362 s.

${ }^{3}$ Кралюк П. М. Роман Мстиславович, князь Волинський і Галицький: іст.-біогр. нарис. Луцьк: Надстир'я, 1999. 76 с.

${ }^{4}$ Головко О. Б. Князь Роман Мстиславич та його доба: нариси 3 історії політичного життя Південної Русі ХІІ - початку ХІІІ століття. К.: Стилос, 2001. 249 с.

${ }^{5}$ Майоров О. В. Галицько-волинський князь Роман Мстиславич. Володар, воїн, дипломат: у 2 т.

Біла Церква: Вид. О. В. Пшонківський, 2011. Т. 1. 318 с.; Т. 2. 462 с.

${ }^{6}$ Горковенко A. B. Меч Романа Галицкого. Князь Роман Мстиславич в истории, эпосе и легендах.

СПб.: Изд. Д. Буланин, 2011. 480 с.

7 Літопис руський: За Іпатським списком / Пер. 3 давньоруської Л. Є. Махновець; відп. ред.

О. В. Мишанич. К.: Дніпро, 1989. 591 с.

8 Зі «Суздальського літопису» // Галицько-Волинський літопис / Переклав і пояснив Т. Коструба.

Львів: Вид. І. Тиктор, 1936. Ч. 1. С. 94-99.

${ }^{9}$ Полное собрание русских летописей (далі - ПСРЛ). СПб.: Археограф. комис., 1843. Т. 2:

Ипатьевская и Густинская летописи. 377 с.

${ }^{10}$ Хониат Н. Никиты Хониата история со времени царствования Иоанна Комнина // Византийские историки, переведенные с греческого при Санкт-Петербургской Духовной Академии: в 2 т. СПб.: Тип. департамента уделов, 1862. Т. 2 / Перевод под ред. проф. Н. В. Чельцова. 541 с.

${ }^{11}$ ПСРЛ. СПб.: Археограф. комис., 1843. Т. 2: Ипатьевская и Густинская летописи. С. 327.

12 Зі «Суздальського літопису» // Галицько-Волинський літопис / Переклав і пояснив Т. Коструба.

Львів: Вид. І. Тиктор, 1936. Ч. 1. С. 94.

13 Зі «Суздальського літопису» // Галицько-Волинський літопис / Переклав і пояснив Т. Коструба. Львів: Вид. І. Тиктор, 1936. Ч. 1. С. 94.

${ }^{14}$ ПСРЛ. СПб.: Археограф. комис., 1843. Т. 2: Ипатьевская и Густинская летописи. С. 328.

${ }^{15}$ Бережков Н. Г. Хронология русского летописания. М.: Изд-во АН СССР, 1963. С. 86.

${ }^{16}$ Соловьев С. М. История России с древнейших времен: в 15 кн. М.: Соцэкгиз, 1959. Кн. 1.

T. 1-2. C. 559.

17 Літопис руський: За Іпатським списком / Пер. 3 давньоруської Л. Є. Махновець; відп. ред.

О. В. Мишанич. К.: Дніпро, 1989. С. 368.

${ }^{18}$ Войтович Л. В. Княжа доба на Русі: портрети еліти. Біла Церква: Вид. О. Пшонківський, 2006. C. 477 .

${ }^{19}$ Пашуто В. Т. Внешняя политика Древней Руси. М.: Наука, 1968. С. 115.

${ }^{20}$ Рыбаков Б. А. Киевская Русь и русские княжества ХІІ-XIII вв. М.: Наука, 1982. С. 495.

${ }^{21}$ Крип'якевич І. П. Галицько-Волинське князівство. 2-ге вид. зі змінами і доповненнями. Львів:

Ін-т українознавства ім. І. Крип’якевича НАН України, 1999. С. 111.

${ }_{22}^{2}$ Котляр М. Ф. Галицько-Волинська Русь // Україна крізь віки: у 15 т. К.: Альтернативи, 1998. T. 5. C. 157

${ }^{23}$ Грушевський М. С. Історія України-Руси: у 11 т., 12 кн. К.: Наук. думка, 1992. Т. 2. С. 224.

${ }^{24}$ Головко О. Б. Корона Данила Галицького: Волинь і Галичина в державно-політичному розвитку Центрально-Східної Європи раннього та класичного середньовіччя. К.: Стилос, 2006. С. 230.

${ }_{25}^{5}$ Котляр М. Ф. Чи міг Роман Мстиславич ходити на половців раніше 1187 р. // УІЖ. 1965. № 1. C. 119-120.

${ }^{26}$ Князький И. О. Славяне, волохи и кочевники Днестровско-Карпатских земель с средины XII ст. до нашествия монголо-татар: автореф. дис. ... канд. ист. наук. М., 1990. С. 8.

27 Головко О. Б. Князь Роман Мстиславич та його доба: нариси з історії політичного життя Південної Русі ХІІ - початку ХІІІ століття. К.: Стилос, 2001. С. 155.

${ }_{28}$ Войтович Л. В. Княжа доба на Русі: портрети еліти. Біла Церква: Вид. О. Пшонківський, 2006. C. 475 .

${ }^{29}$ Котляр М. Ф. Воєнне мистецтво Давньої Русі. К.: Наш час, 2011. С. 181. 560-561.

${ }^{30}$ Грушевський М. С. Історія України-Руси: у 11 т., 12 кн. К.: Наук. думка, 1992. Т. 2. С. 226,

${ }^{31}$ Бережков Н. Г. Хронология русского летописания. М.: Изд-во АН СССР, 1963. С. 87.

${ }^{32}$ Войтович Л. В. Галицько-Волинські етюди. Біла Церква: Вид. О. Пшонківський, 2011. С. 220.

33 Літопис руський: За Іпатським списком / Пер. 3 давньоруської Л. Є. Махновець; відп. ред. О. В. Мишанич. К.: Дніпро, 1989. С. 368. 
34 Левченко М. В. Очерки по истории русско-византийских отношений. М.: Изд-во АН СССР, 1956. C. 496.

${ }^{35}$ Майоров О. В. Галицько-волинський князь Роман Мстиславич. Володар, воїн, дипломат: у 2 т. Біла Церква: Вид. О. В. Пшонківський, 2011. Т. 1. 318 с.; Т. 2. С. 254-255.

${ }^{36}$ Пашуто В. Т. Внешняя политика Древней Руси. М.: Наука, 1968. С. 201.

${ }^{37}$ Рыбаков Б. А. Киевская Русь и русские княжества XII-XIII вв. М.: Наука, 1982. С. 495.

${ }^{38}$ Крип'якевич І. П. Галицько-Волинське князівство. 2-ге вид. зі змінами і доповненнями. Львів: Ін-т українознавства ім. І. Крип’якевича НАН України, 1999. С. 112.

${ }^{39}$ Головко О. Б. Корона Данила Галицького: Волинь і Галичина в державно-політичному розвитку Центрально-Східної Свропи раннього та класичного середньовіччя. К.: Стилос, 2006. С. 230.

${ }^{40}$ Хониат Н. Никиты Хониата история со времени царствования Иоанна Комнина // Византийские историки, переведенные с греческого при Санкт-Петербургской Духовной Академии: в 2 т. СПб.: Тип. департамента уделов, 1862. Т. 2 / Перевод под ред. проф. Н. В. Чельцова. С. 245-246.

41 Зі «Суздальського літопису» // Галицько-Волинський літопис / Переклав і пояснив Т. Коструба. Львів: Вид. І. Тиктор, 1936. Ч. 1. С. 94.

42 Путешествие новгородского архиепископа Антония в Царьград в конце 12-го столетия. С предисловием и примечаниями П. Савваитова. СПб.: Изд. Археограф. комис., 1872. С. 77-78.

${ }^{43}$ Майоров О. В. Галицько-волинський князь Роман Мстиславич. Володар, воїн, дипломат: у 2 т. Біла Церква: Вид. О. В. Пшонківський, 2011. Т. 1. 318 с.; Т. 2. С. 258.

${ }_{44}$ Літопис руський: За Іпатським списком / Пер. 3 давньоруської Л. С. Махновець; відп. ред. О. В. Мишанич. К.: Дніпро, 1989. С. 369.

${ }^{45}$ Войтович Л. В. Княжа доба на Русі: портрети еліти. Біла Церква: Вид. О. Пшонківський, 2006. C. 476

${ }^{46}$ Пашуто В. Т. Очерки по истории Галицко-Волынской Руси. М.: Изд-во АН СССР, 1950. C. 194.

${ }^{47}$ Полонська-Василенко Н. Княгиня Романова Ганна // Визвольний шлях. 1954. Кн. 3. С. $57-64$.

48 Котляр $M . \Phi$. До питання про візантійське походження матері Данила Галицького // Археологія. 1991. № 2. С. 48-58; Його ж. Княгиня Анна // Історія України в особах IX-XVIII ст. / За ред. В. Замлинського. К.: Україна, 1993. С. 117-119; Його ж. Історія дипломатії Південно-Західної Русі. К.: Ін-т історії України НАН України, 2002. С. 77-78; Його ж. Дипломатия Южной Руси. СПб.: Алетейя, 2003. С. 97-102.

49 Головко О. Б. Князь Роман Мстиславич та його доба: нариси з історії політичного життя Південної Русі XII - початку XIII століття. К.: Стилос, 2001. С. 141-142.

${ }^{50}$ Головко О. Б. Візантійська імперія, Південна Русь і Половецький степ в політичній діяльності галицько-волинського князя Романа Мстиславича // Орієнтальні студії в Україні. До ювілею Л. В. Матвєєвої. К.: Ін-т сходознавства ім. А. Ю. Кримського, 2010. С. 192-208.

${ }^{51}$ Bieniak J. Roman // Słownik starożytności słowiańskich. Wrocław: Ossolineum, 1970. T. 4. S. 534536.

52 Грицак П. Галицько-Волинська держава. Нью-Йорк: НТШ, 1958. С. 55.

${ }^{53}$ Droba L. Stosunki Leszka Białego z Rusią i Węgrami // Rozprawy Akademii Umiejętności. Wydział Historyczno-Filozoficzny. Kraków: Akademia Umiejętności, 1881. T. 13. S. 37.

${ }^{54}$ Abraham $W$. Powstanie organizacji kościoła łacińskiego na Rusi. Lwów: Nakładem. Towarzystwa dla popierania nauki polskiej, 1904. T. 1. S. 98.

${ }^{55}$ Wtodarski B. Polska i Ruś: 1194-1340. Warszawa: PWN, 1966. S. 24-25.

56 Луиів В. Володар Роман Мстиславович // Визвольний шлях. 1964. № 4. С. 414.

${ }^{57}$ Forsmann J. Die Beziehungen altrussischer Fürstengeschlechter zu Westeuropa. Ein Beitrag zur Geschichte Ost- und Nordeuropas im Mittelalter mit 22 Stammtafeln ost- und nordeuropaischer Fürsten. Bern: Herbert Lang, 1970. S. 139.

58 Чубатий М. Історія християнства на Руси-Україні. Рим; Нью-Йорк: Укр. Католицький ун-т, 1965. Т. 1: До року 1353. С. 567-568.

59 Толочко О. П. Як звали другу дружину Романа Мстиславича // Confraternitas. Ювілейний збірник на пошану Я. Ісаєвича / Відп. ред. М. Крикун // Україна: культурна спадщина, національна свідомість, державність: Зб. наук. пр. Вип. 15. Львів: Ін-т українознавства ім. І. Крип’якевича НАН України, 2006-2007. С. 99.

${ }^{60}$ Грушевський М. С. Історія України-Руси: у 11 т., 12 кн. К.: Наук. думка, 1993. Т. 3. С. 72.

${ }^{61}$ Томашівський С. Українська історія: нарис. Львів: Вид-во «Вчора і нині», 1919. Т. 1: Старинні часи і середні віки. С. 90.

${ }^{62}$ Крип 'якевич I. П. Галицько-Волинське князівство. 2-ге вид. зі змінами і доповненнями. Львів: Ін-т українознавства ім. І. Крип’якевича НАН України, 1999. С. 114.

${ }^{63}$ Kazhdan A. Ruś - Byzantine Princely Marriages in the Eleventh and Twelfth Centuries // Harvard Ukrainian Studies. 1988-1989. T. 12-13. P. 424.

${ }^{64}$ Войтович Л. В. Галич у політичному житті Свропи XI-XIVстоліть. Львів: Ін-т українознавства ім. І. Крип'якевича НАН України, 2015. С. 113. 
${ }^{65}$ Баумгартен Н. Вторая ветвь князей галицких. Потомство Романа Мстиславича // Летопись Историко-родословного общества в Москве. 1909. Вып. 1 (17). С. 9-11.

${ }^{66}$ Grala H. Drugie małżeństwo Romana Mścisławowicza // Slavia Orientalis. Warszawa, 1982. R. 31. № 3-4. S. 116-123.

${ }^{67}$ Dąbrowski D. Rodowód Romanowiczów książąt halicko-wołyńskich. Poznań; Wrocław: Wydawnictwo Historyczne, 2002. S. 34-40; Його ж. Genealogia Mścisławowiczów. Pierwsze pokolenia (do początku XIV wieku). Kraków: Awalon, 2008. S. 265-266.

${ }_{68}$ Войтович Л. В. Князівські династії Східної Свропи (кінець IX - початок XVI ст.): склад, суспільна і політична роль: історико-генеалогічне дослідження. Львів: Ін-т українознавства ім. І. Крип'якевича НАН України, 2000. С. 67, 71-72, 224, 376, 380-281; Його ж. Княжа доба на Русі: портрети еліти. Біла Церква: Вид. О. Пшонківський, 2006. С. 484; Його ж. Союз Візантії та Галицько-Волинської держави за династії Ангелів // Княжа доба: історія і культура. Вип. 2. Львів: Ін-т українознавства ім. І. Крип’якевича НАН України, 2008. С. 37.

${ }_{69}$ Майоров О. В. Галицько-волинський князь Роман Мстиславич. Володар, воїн, дипломат: у 2 т. Біла Церква: Вид. О. В. Пшонківський, 2011. Т. 1. С. 208.

${ }^{70}$ Nagirnyj W. Polityka zagraniczna księstw ziem Halickiej i Wołyńskiej w latach 1198(1199)-1264//

Prace Komisji wschodnioeuropejskiej PAU / Pod red. A. A. Zięby. Kraków: PAU, 2011. T. 12. S. 96.

${ }^{71}$ Grala H. Drugie małżeństwo Romana Mścisławowicza // Slavia Orientalis. Warszawa, 1982. R. 31. № 3-4. S. 116-123; Його ж. Rola Rusi w wojnach bizantyńsko-bułgarskich przełomu XII i XIII w. // Balcanica Posnaniensia. Acta et Studia. Poznań, 1985. T. 2. S. 128-131.

72 Літопис руський: За Іпатським списком / Пер. $з$ давньоруської Л. С. Махновець; відп. ред. О. В. Мишанич. К.: Дніпро, 1989. С. 369.

73 Dabrowski D. Genealogia Mścisławowiczów. Pierwsze pokolenia (do początku XIV wieku). Kraków: Awalon, 2008. S. 265.

${ }^{74}$ Майоров О. В. Галицько-волинський князь Роман Мстиславич. Володар, воїн, дипломат: у 2 т. Біла Церква: Вид. О. В. Пшонківський, 2011. Т. 2. С. 338; Його ж. Єфросинія Галицька. Дочка візантійського імператора в Галицько-Волинській Русі: княгиня і черниця. Біла Церква: Вид. О. В. Пшонківський, 2013. С. 21.

${ }^{75}$ Майоров О. В. Галицько-волинський князь Роман Мстиславич. Володар, воїн, дипломат: у 2 т. Біла Церква: Вид. О. В. Пшонківський, 2011. Т. 2. С. 347; Його ж. Єфросинія Галицька. Дочка візантійського імператора в Галицько-Волинській Русі: княгиня і черниця. Біла Церква: Вид. О. В. Пшонківський, 2013. С. 30.

${ }_{76}$ Майоров О. В. Галицько-волинський князь Роман Мстиславич. Володар, воїн, дипломат: у 2 т. Біла Церква: Вид. О. В. Пшонківський, 2011. Т. 2. С. 381; Його ж. Єфросинія Галицька. Дочка візантійського імператора в Галицько-Волинській Русі: княгиня і черниця. Біла Церква: Вид. О. В. Пшонківський, 2013. С. 64-65.

77 Майоров О. В. Галицько-волинський князь Роман Мстиславич. Володар, воїн, дипломат: у 2 т. Біла Церква: Вид. О. В. Пшонківський, 2011. Т. 2. С. 488; Його ж. Єфросинія Галицька. Дочка візантійського імператора в Галицько-Волинській Русі: княгиня і черниця. Біла Церква: Вид. О. В. Пшонківський, 2013. С. 124.

${ }^{78}$ Войтович Л. В. Галич у політичному житті Свропи XI-XIVстоліть. Львів: Ін-т українознавства ім. І. Крип'якевича НАН України, 2015. С. 114.

${ }^{79}$ Grala H. Drugie małżeństwo Romana Mścisławowicza // Slavia Orientalis. Warszawa, 1982. R. 31. № 3-4. S. 116-123; Його ж. Rola Rusi w wojnach bizantyńsko-bułgarskich przełomu XII i XIII w. // Balcanica Posnaniensia. Acta et Studia. Poznań, 1985. T. 2. S. 128-131.

${ }^{80}$ Dabrowski D. Rodowód Romanowiczów książąt halicko-wołyńskich. Poznań; Wrocław: Wydawnictwo Historyczne, 2002. S. 40; Його ж. Genealogia Mścisławowiczów. Pierwsze pokolenia (do początku XIV wieku). Kraków: Awalon, 2008. S. 265.

${ }^{81}$ Nagirnyj W. Polityka zagraniczna księstw ziem Halickiej i Wołyńskiej w latach 1198(1199)-1264//

Prace Komisji wschodnioeuropejskiej PAU / Pod red. A. A. Zięby. Kraków: PAU, 2011. T. 12. S. 97.

82 Войтович Л. В. Князівські династії Східної Свропи (кінець IX - початок XVI ст.): склад, суспільна і політична роль: історико-генеалогічне дослідження. Львів: Ін-т українознавства ім. I. Крип'якевича НАН України, 2000. С. 224; Його ж. Княжа доба на Русі: портрети еліти. Біла Церква: Вид. О. Пшонківський, 2006. С. 487.

${ }^{83}$ Майоров О. В. Галицько-волинський князь Роман Мстиславич. Володар, воїн, дипломат: у 2 т. Біла Церква: Вид. О. В. Пшонківський, 2011. Т. 2. С. 488; Його ж. Єфросинія Галицька. Дочка візантійського імператора в Галицько-Волинській Русі: княгиня і черниця. Біла Церква: Вид. О. В. Пшонківський, 2013. С. 124.

84 Толочко А. П. Известен ли год рождения Даниила Романовича Галицкого? // Средневековая Русь. 2007. № 7. С. 234-235.

${ }^{85}$ Хониат Н. Никиты Хониата история со времени царствования Иоанна Комнина // Византийские историки, переведенные с греческого при Санкт-Петербургской Духовной Академии: в 2 т. СПб.: Тип. департамента уделов, 1862. Т. 2 / Перевод под ред. проф. Н. В. Чельцова. С. 245-246. 
${ }^{86}$ Майоров О. В. Галицько-волинський князь Роман Мстиславич. Володар, воїн, дипломат: у 2 т. Біла Церква: Вид. О. В. Пшонківський, 2011. Т. 1. С. 262.

87 Зі «Суздальського літопису» // Галицько-Волинський літопис / Переклав і пояснив Т. Коструба. Львів: Вид. І. Тиктор, 1936. Ч. 1. С. 94.

${ }^{88}$ Грушевський М. С. Історія України-Руси: у 11 т., 12 кн. К.: Наук. думка, 1992. Т. 2. С. 227.

89 Хониат Н. Никиты Хониата история со времени царствования Иоанна Комнина // Византийские историки, переведенные с греческого при Санкт-Петербургской Духовной Академии: в 2 т. СПб.: Тип. департамента уделов, 1862. Т. 2 / Перевод под ред. проф. Н. В. Чельцова. C. $245-246$.

${ }^{90}$ Книга Паломник. Сказание мест святых во Цареграде Антония, архиепископа Новгородского, в 1200 г. / Под ред. Х. М. Лопарева // Православный Палестинский сборник. Вып. 51. Т. 15. СПб.: Правосл. Палест. об-во, 1899. С. 15; Путешествие новгородского архиепископа Антония в Царьград в конце 12-го столетия. С предисловием и примечаниями П. Савваитова. СПб.: Изд. Археограф. комис., 1872. С. 78-79.

${ }_{91}$ Феннел Дж. Кризис средневековой Руси. 1200-1304 / Пер. с англ. В. В. Голубчикова. М.: Прогресс, 1989. С. 64.

${ }_{92}$ Головко О. Б. Південна Русь і половецький степ у політичній діяльності галицько-волинського князя Романа Мстиславича // Українська козацька держава: витоки та шляхи історичного розвитку: матеріали Других Всеукраїнських читань). Черкаси, 1992. С. 16.

${ }^{93}$ Кучинко М. М. Нариси стародавньої і середньовічної історії Волині (від палеоліту до середини XIV ст.). Луцьк: Надстир'я, 1994. С. 173-174; Його ж. Волинська земля в X - першій половині XIV ст.: дис. ... д-ра іст. наук. Луцьк, 1998. С. 344.

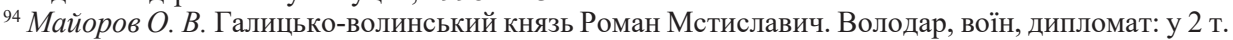
Біла Церква: Вид. О. В. Пшонківський, 2011. Т. 2. С. 713.

${ }_{95}$ Головко О. Б. Князь Роман Мстиславич та його доба: нариси з історії політичного життя Південної Русі XII - початку XIII століття. К.: Стилос, 2001. С. 162.

${ }_{96}^{96}$ Крип'якевич I. П. Галицько-Волинське князівство. 2-ге вид. зі змінами і доповненнями. Львів: Ін-т українознавства ім. І. Крип’якевича НАН України, 1999. С. 112.

${ }_{97}$ Котляр Н. Ф. Дипломатия Южной Руси. СПб.: Алетейя, 2003. С. 266; Його ж. Воєнне мистецтво Давньої Русі. К.: Наш час, 2011. С. 181.

${ }_{98}$ Грушевський М. С. Історія України-Руси: у 11 т., 12 кн. К.: Наук. думка, 1993. Т. 3. С. 10.

${ }_{99}$ Рыбаков Б. А. Киевская Русь и русские княжества XII-XIII вв. М.: Наука, 1982. С. 495.

${ }^{100}$ Войтович Л. В. Княжа доба на Русі: портрети еліти. Біла Церква: Вид. О. Пшонківський, 2006. C. 477.

101 Літопис руський: За Іпатським списком / Пер. з давньоруської Л. Є. Махновець; відп. ред. О. В. Мишанич. К.: Дніпро, 1989. С. 368.

102 Феннел Дж. Кризис средневековой Руси. 1200-1304 / Пер. с англ. В. В. Голубчикова. М.: Прогресс, 1989. С. 65.

${ }_{103}$ Головко О. Б. Князь Роман Мстиславич та його доба: нариси з історії політичного життя Південної Русі XII - початку XIII століття. К.: Стилос, 2001. С. 160-163.

104 Волощук М. М. Військово-політичні стосунки Угорського королівства з Галицьким та Галицько-Волинським князівством (кінець XII-XIII ст.): дис. ... канд. іст. наук. Івано-Франківськ, 2005. C. 65.

${ }_{105}$ Толочко А. П. «История Российская» Василия Татищева: источники и известия. М.: Новое литературное обозрение; К.: Критика, 2005. С. 289.

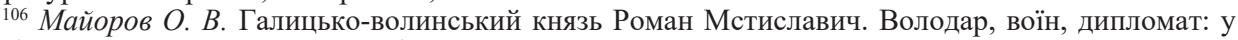
2 т. Біла Церква: Вид. О. В. Пшонківський, 2011. Т. 1. С. 286, 291.

107 Літопис руський: За Іпатським списком / Пер. 3 давньоруської Л. Є. Махновець; відп. ред. О. В. Мишанич. К.: Дніпро, 1989. С. 368.

${ }_{108}$ Кійко В. I. Військова справа у Галицькому та Волинському князівствах, XI-XIV ст.: дис. ... канд. іст. наук. Львів, 2009. С. 58.

109 Зі «Суздальського літопису» // Галицько-Волинський літопис / Переклав і пояснив Т. Коструба. Львів: Вид. І. Тиктор, 1936. Ч. 1. С. 99.

${ }_{110}$ Новгородская первая летопись старшего и младшего изводов / Под ред. и с предисловием А. Насонова. М.; Л.: Изд-во АН СССР, 1950. С. 240.

111 Хониат H. Никиты Хониата история со времени царствования Иоанна Комнина // Византийские историки, переведенные с греческого при Санкт-Петербургской Духовной Академии: в 2 т. СПб.: Тип. департамента уделов, 1862. Т. 2 / Перевод под ред. проф. Н. В. Чельцова. С. 245-246.

$1123 \mathrm{i}$ «Суздальського літопису» // Галицько-Волинський літопис / Переклав і пояснив Т. Коструба. Львів: Вид. І. Тиктор, 1936. Ч. 1. С. 96.

${ }^{113}$ Грушевський М. С. Історія України-Руси: у 11 т., 12 кн. К.: Наук. думка, 1993. Т. 3. С. 9.

114 Літопис руський: За Іпатським списком / Пер. $з$ давньоруської Л. Є. Махновець; відп. ред. О. В. Мишанич. К.: Дніпро, 1989. С. 368. 
115 Толочко О. П., Толочко П. П. Київська Русь // Україна крізь віки: у 15 т. К.: Альтернативи, 1998. T. 4. C. 257.

${ }_{116}$ Татищев В. Н. История Российская: в 7 т. М., Л.: Наука, 1964. Т. 3. С. 116.

${ }^{117}$ Котляр М. Ф. Данило Галицький: біографічний нарис. К.: Альтернативи, 2002. С. 52.

118 Майоров О. В. Галицько-волинський князь Роман Мстиславич. Володар, воїн, дипломат: у 2 т. Біла Церква: Вид. О. В. Пшонківський, 2011. Т. 1. С. 294.

${ }_{119}$ Войтович Л. В. Княжа доба на Русі: портрети еліти. Біла Церква: Вид. О. Пшонківський, 2006. C. 479; Його ж. Галич у політичному житті Європи XI-XIVстоліть. Львів: Ін-т українознавства ім. I. Крип'якевича НАН України, 2015. С. 115.

120 Літопис руський: За Іпатським списком / Пер. $з$ давньоруської Л. Є. Махновець; відп. ред. О. В. Мишанич. К.: Дніпро, 1989. 591 с.

${ }^{121}$ Щавелева Н. И. Древняя Русь в «Польской истории» Яна Длугоша (Книги I-VI): текст, перевод, комментарий. М.: Памятники исторической мысли, 2004. С. 343; ПСРЛ. СПб.: Археограф. комис., 1843. Т. 2: Ипатьевская и Густинская летописи. С. 327.

122 Зубриикий Д. И. История древнего Галичско-Русского княжества: в 3 ч. Львов: Тип. Ставропиг. ин-та, 1852-1855. Ч. 3. С. 20; Дашкевич Н. П. Княжение Даниила Галицкого, по русским и иностранным известиям. К.: Унив. тип., 1873. С. 96; Андриящев А. М. Очерк по истории Волынской земли до конца XIV ст. К.: Тип. Имп. ун-та Св. Владимира, 1887. С. 152; Мавродин В. В. Очерк истории Древней Руси до монгольского завоевания // История культуры Древней Руси. Домонгольский период. Материальная культура / Под ред. Б. Д. Грекова, М. И. Артамонова, Н. Н. Воронина: в 2 т. М.; Л.: Изд-во АН СССР, 1948-1951. Т. 1. С. 35; Лихачев Д. С. Комментарий исторический и географический // Слово о полку Игореве / АН СССР; Под ред. В. П. Адриановой-Перетц. М.; Л.: Изд-во АН СССР, 1950. С. 445; Коструба Т. Вибрані твори. Торонто: Добра книжка, 1961. Т. 2. C. 253; Forsmann J. Die Beziehungen altrussischer Fürstengeschlechter zu Westeuropa. Ein Beitrag zur Geschichte Ost- und Nordeuropas im Mittelalter mit 22 Stammtafeln ost- und nordeuropaischer Fürsten. Bern: Herbert Lang, 1970. S. 126; Prinzing G. Die Bedeutung Bulgariens und Serbiens in den Jahren 1204 1219 im Zusammenhang mit der Entstehung und Entwicklung der byzantinischen Teilstaaten nach der Einnahme Konstantinopels infolge des 4. Kreuzzuges. München, 1972. S. 7, 19; Рыбаков Б. А. Киевская Русь и русские княжества XII-XIII вв. М.: Наука, 1982. С. 515; Александров Д. Н. Южная, ЮгоЗападная и Центральная Русь в XIII-XIV вв. и образование Литовского государства. М.: Рос. акад. естественных наук, 1994. С. 52; Борисенко В. Й. Курс української історії. 3 давніших часів до ХХ ст. К.: Либідь, 1996. С. 77; Яковенко Н. М. Нарис історії України. 3 найдавніших часів до кінця XVIII століття: навч. пос. К.: Генеза, 1997. С. 71; Грабовецький В. В. Галич - столиця Ростиславовичів і Романовичів у міжнародних взаєминах XII-XIII ст. // Галич і Галицька земля: зб. наук. праць / Відп. ред. П. П. Толочко. К.; Галич: ІА НАНУ; НЗ «Давній Галич», 1998. С. 43; Ісаєвич Я. Д. ГалицькоВолинська держава: короткий нарис історії галицько-волинських земель в кінці XI-XIV ст. Львів: Ін-т українознавства ім. І. Крип'якевича НАН України, 1999. С. 13; Войтович Л. В. Княжа доба на Русі: портрети еліти. Біла Церква: Вид. О. Пшонківський, 2006. С. 480; Iдзьо В. С. Українська держава в IX-XIII століттях. Львів: Сполом, 2004. С. 204.

123 Грушевський М. С. Історія України-Руси: у 11 т., 12 кн. К.: Наук. думка, 1993. Т. 3. С. 12; Nagirnyj W. Polityka zagraniczna księstw ziem Halickiej i Wołyńskiej w latach 1198(1199)-1264 // Prace Komisji wschodnioeuropejskiej PAU / Pod red. A. A. Zięby. Kraków: PAU, 2011. T. 12. S. 100-108.

${ }^{124}$ Котляр М. Ф. До питання про втечу візантійського імператора в Галич у 1204 р. // УІЖ. 1966. № 3. С. 112-117; Його ж. Дипломатия Южной Руси. СПб.: Алетейя, 2003. С. 89-97.

${ }^{125}$ Grala H. Tradycija dziejopisarska o pobycie władcy Bizancjum w Haliczu (Jan Długosz i kronikars Hustyński) // Kwartalnik Historyczny. 1986. R. 93. № 3. S. 650-651.

${ }^{126}$ Майоров O. В. Ангел в Галичі: чи міг візантійський імператор Олексій III відвідувати Романа Мстиславича // Княжа доба: історія і культура. Вип. 3. Львів: Ін-т українознавства ім. І. Крип’якевича НАН України, 2010. С. 133-164; Його ж. Галицько-волинський князь Роман Мстиславич. Володар, воїн, дипломат: у 2 т. Біла Церква: Вид. О. В. Пшонківський, 2011. Т. 1. С. 221-230.

${ }^{127}$ Chronica Albrici monachi Trium fontium, a monacho Novi monasterii hoiensis interpolata. 1241

/ Ed. P. Scheffer-Boichorst // Monumenta Germaniae Historica, Scriptores. Hannoverae, 1874. T. 23. P. 881.

128 Хониат H. Никиты Хониата история со времени царствования Иоанна Комнина // Византийские историки, переведенные с греческого при Санкт-Петербургской Духовной Академии: в 2 т. СПб.: Тип. департамента уделов, 1862. Т. 2 / Перевод под ред. проф. Н. В. Чельцова. С. $283,296$.

${ }^{129}$ Майоров О. В. Ангел в Галичі: чи міг візантійський імператор Олексій III відвідувати Романа Мстиславича // Княжа доба: історія і культура. Вип. 3. Львів: Ін-т українознавства ім. І. Крип’якевича НАН України, 2010. С. 155; Його ж. Галицько-волинський князь Роман Мстиславич. Володар, воїн, дипломат: у 2 т. Біла Церква: Вид. О. В. Пшонківський, 2011. Т. 1. С. 235.

${ }_{130}$ Майоров О. В. Галицько-волинський князь Роман Мстиславич. Володар, воїн, дипломат: у 2 т. Біла Церква: Вид. О. В. Пшонківський, 2011. Т. 1. С. 215.

${ }^{131}$ Котляр Н. Ф. Дипломатия Южной Руси. СПб.: Алетейя, 2003. С. 95. 
132 Майоров О. В. Галицько-волинський князь Роман Мстиславич. Володар, воїн, дипломат: у 2 т. Біла Церква: Вид. О. В. Пшонківський, 2011. Т. 1. С. 226.

${ }_{133}$ Войтович Л. В. Союз Візантії та Галицько-Волинської держави за династії Ангелів // Княжа доба: історія і культура. Вип. 2. Львів: Ін-т українознавства ім. І. Крип'якевича НАН України, 2008. C. 39 .

${ }_{134}$ Майоров О. В. Галицько-волинський князь Роман Мстиславич. Володар, воїн, дипломат: у 2 т. Біла Церква: Вид. О. В. Пшонківський, 2011. Т. 1. С. 208.; Т. 2. С. 718.

135 Библиотека Российская историческая, содержащая древние летописи и всякие записки, способствующие к объяснению истории и географии российской древних и средних времен / Сост.: С. С. Башилов, И. И. Тауберт. СПб.: Имп. АН, 1767. Ч. 1: Летопись Несторова с продолжателями по Кенигсбергскому списку, до 1206 года. С. 299-301.

${ }^{136}$ Войтович Л. В. Галич у політичному житті Європи XI-XIVстоліть. Львів: Ін-т українознавства ім. І. Крип’якевича НАН України, 2015. С. 121.

137 Библиотека Российская историческая, содержащая древние летописи и всякие записки, способствующие к объяснению истории и географии российской древних и средних времен / Сост.: С. С. Башилов, И. И. Тауберт. СПб.: Имп. АН, 1767. Ч. 1: Летопись Несторова с продолжателями по Кенигсбергскому списку, до 1206 года. С. 300-301.

${ }_{138}$ Библиотека Российская историческая, содержащая древние летописи и всякие записки, способствующие к объяснению истории и географии российской древних и средних времен / Сост.: С. С. Башилов, И. И. Тауберт. СПб.: Имп. АН, 1767. Ч. 1: Летопись Несторова с продолжателями по Кенигсбергскому списку, до 1206 года. С. 300-301.

${ }^{139}$ Chronica Albrici monachi Trium fontium, a monacho Novi monasterii hoiensis interpolata. 1241 /

Ed. P. Scheffer-Boichorst // Monumenta Germaniae Historica, Scriptores. Hannoverae, 1874. T. 23. P. 885.

${ }_{140}$ Паславський I. Коронація Данила Галицького в контексті політичних і церковних відносин XIII століття / Ін-т українознавства ім. І. Крип'якевича. Львів: Місіонер, 2003. С. 24.

${ }^{141}$ Майоров О. В. Галицько-волинський князь Роман Мстиславич. Володар, воїн, дипломат: у 2 т. Біла Церква: Вид. О. В. Пшонківський, 2011. Т. 1. С. 164.

${ }^{142}$ Historia dyplomacji polskiej: (połowa X-XX w.) / Pod red. G. Labudy. Wyd. 2. Warszawa: PWN, 1982. T. 1: Połowa X w. - 1572 / Pod red. M. Biskupa. S. 144-145.

${ }^{143}$ Włodarski B. Polityka ruska Leszka Białego. Lwów: Tow. Naukowe, 1925. S. 19-21; Пamymo B. T. Внешняя политика Древней Руси. М.: Наука, 1968. С. 165, 344; Щавелева Н. И. Польские латиноязычные средневековые источники: тексты, перевод, комментарий / АН СССР; Ин-т истории СССР; отв. ред. В. Л. Янин. М.: Наука, 1990. С. 152.

144 Зі «Суздальського літопису» // Галицько-Волинський літопис / Переклав і пояснив Т. Коструба. Львів: Вид. І. Тиктор, 1936. Ч. 1. С. 96.

${ }^{145}$ Войтович Л. В. Галицько-Волинські етюди. Біла Церква: Вид. О. Пшонківський, 2011. С. 228. 